\title{
Effect of nutrient management approaches on the quality of soil and crops, sustainability of yield in maize - chickpea sequential cropping system
}

\author{
B. V. SHREENIVAS*, M. V. RAVI AND H. S. LATHA \\ Department of Soil Science and Agricultural Chemistry, University of Agricultural Sciences, \\ RAICHUR (KARNATAKA) INDIA
}

\begin{abstract}
Field experiments were conducted during 2010-11 and 2011-12 at Agricultural Research Station, Raddewadagi, Jewargi taluk, Kalaburagi district, University of Agricultural Sciences, Raichur to study the nutrient management approaches on the quality of soil and crops, sustainability of yield in maize-chickpea sequential cropping system involving SSNM and STCR targeted yield of 7 or $8 \mathrm{t} \mathrm{ha}^{-1}$ in clayey soils of Vertisol of UKP area. The application of nutrients through SSNM approach for targeted yield of $8.0 \mathrm{t} \mathrm{ha}^{-1}$ produced significantly higher grain yield and sustainability yield index ( 8.62 and 0.80 , respectively) as compared to absolute control, farmers practice, state recommendation and STL method and it was at par with STCR approach for targeted yield of $8.0 \mathrm{t} \mathrm{ha}^{-1}\left(8.37 \mathrm{tha}^{-1}\right.$ and 0.77 , respectively), SSNM approach for targeted yield of $7.0 \mathrm{t} \mathrm{ha}^{-1}\left(7.59, \mathrm{t} \mathrm{ha}^{-1}\right.$ and 0.68 , respectively), STCR approach for targeted yield of $7.0 \mathrm{t} \mathrm{ha}^{-1}\left(7.46 \mathrm{t} \mathrm{ha}^{-1}\right.$ and 0.67 , respectively), 125 per cent SSNM approach for targeted yield of $8.0 \mathrm{tha}^{-1}\left(6.45 \mathrm{tha}^{-1}\right.$ and 0.55 , respectively) and 125 per cent SSNM approach for targeted yield of $7.0 \mathrm{t} \mathrm{ha}^{-1}(6.35$, $\mathrm{t} \mathrm{ha}^{-1}$ and 0.54 , respectively). Organic carbon content was non-significant in maize-chickpea sequence cropping system. However, significantly higher available $\mathrm{N}, \mathrm{P}_{2} \mathrm{O}_{5}$ and $\mathrm{K}_{2} \mathrm{O}\left(301.05,62.93\right.$ and $439.38 \mathrm{~kg} \mathrm{ha}^{-1}$, respectively) were noticed with nutrients applied through 125 per cent SSNM approach for targeted yield of $8.0 \mathrm{t} \mathrm{ha}^{-1}$ as compared to absolute control, farmers practice, state recommendation, STL method and 125 per cent SSNM approach for targeted yield of $7.0 \mathrm{t} \mathrm{ha}^{-1}$ after harvest of second crop in maize-chickpea sequence cropping system and it was at par with SSNM or STCR approach for targeted yield of 7.0 or 8.0 $\mathrm{t} \mathrm{ha}^{-1}$. Application of nutrients through SSNM approach for targeted yield of $8.0 \mathrm{t} \mathrm{ha}^{-1}$ recorded significantly higher protein $(6.59 \%)$ and protein yield $\left(568.01 \mathrm{~kg} \mathrm{ha}^{-1}\right)$ and also its residual effect was recorded significantly higher protein content $(20.28 \%)$ and protein yield $\left(606.31 \mathrm{~kg} \mathrm{ha}^{-1}\right)$ in chickpea as compared to other treatments.
\end{abstract}

Key Words : Maize-chickpea sequential cropping system, Grain yield, Sustainability yield index, SSNM, STCR, Protein, Protein yield

View Point Article : Shreenivas, B.V., Ravi, M.V. and Latha, H.S. (2017). Effect of nutrient management approaches on the quality of soil and crops, sustainability of yield in maize - chickpea sequential cropping system. Internat. J. agric. Sci., 13 (2) : 353-359, DOI:10.15740/ HAS/IJAS/13.2/353-359.

Article History : Received : 17.03.2017; Revised : 29.04.2017; Accepted : 13.05.2017

\footnotetext{
* Author for correspondence:
} 